\title{
The Contribution of Religious Education to the Prevention of Antisemitism: An International Empirical Study
}

\begin{abstract}
This research project is situated in the Europe-wide discussion on historical remembrance and the challenges of antisemitism today. The specific emphasis of the study is Holocaust remembrance in religious education. Within this horizon, we examine the practice of religious education by analyzing how the complex topic of Holocaust remembrance and antisemitism is approached and perceived by pupils and teachers in the context of this specific school subject. The research project asks, by means of an international comparative approach, how the topic of Holocaust remembrance and antisemitism is dealt with within religious education in the curriculum of secondary schools in Germany, Austria, and Switzerland. Going beyond the theoretical and mostly normative discourse, the emphasis is set on the empirical investigation of the practice of religious education focusing on antisemitism. This was examined in all three countries via an online questionnaire. This approach provides an overview and statistical data about various ways of teaching Holocaust remembrance and about antisemitism. Part of the online questionnaire is a qualitative analysis of short texts written by teachers involved and initiated by open questions. Additional interviews provide deeper insight of the teachers' experiences, obstacles, and achievements in class while covering the topic of antisemitism.
\end{abstract}

\section{Introduction}

Antisemitism is not only a problem of society and nations, it is also a problem of religious communities and denominations. For more than two-thousand years Christian anti-Judaism and antisemitism are part of Christian tradition and can be found in holy texts, Christian sermons, rituals, teaching, and religiously motivated actions. For the last fourteen-hundred years Muslim anti-Judaism and antisemitism can be found in Islamic tradition.

In times of resurgent antisemitism in all parts of the world, ${ }^{1}$ the serious task of any religious tradition is to rethink, rework, and renew their doctrines and principles with respect to antisemitic teachings and attitudes. Christianity has a most important task in this respect, because Christian enmity against Jews is the central source for the emergence of modern antisemitism.

1 Cf. A. H. Rosenfeld, Resurgent Antisemitism: Global Perspectives (Bloomington: Indiana University Press, 2013).

Ә OpenAccess. (C) 2022 Reinhold Boschki, published by De Gruyter. (cc))BY-NC-ND This work is licensed under the Creative Commons Attribution-NonCommercial-NoDerivatives 4.0 International License. 
"Christian anti-Judaism provided elements for an ideology adopted in modern anti-Semitism."2 This quote expresses the entire drama of the question of religious anti-Judaism and antisemitism. Historically, Christianity cannot apologize for a supposedly less dangerous anti-Judaism, which would have little to do with the emergence of modern racial antisemitism. On the contrary, religious antisemitism and social, political, right-wing extremist or even state antisemitism are intimately interwoven. Historians such as Yehuda Bauer assume that Christian antisemitism is consistent with modern antisemitism. ${ }^{3}$

The Christian roots of antisemitism are also evident in current manifestations of hatred against Jews in European societies. Often religious or pseudoreligious patterns are applied to Judaism (e.g., demonization, bedevilment, and satanization of the Jews), borrowed from the history of religious hatred of the Jews and transferred to today's forms of antisemitism. For this reason, churches, theology, and religious education must grapple with and tackle the problem of antisemitism in today's societies as an issue of their own.

As I am not a historian it is not my task and not my competence to give an overview of Christian anti-Judaism and antisemitism. Many contributions are included in this volume that report and discuss research on the historical and sociological background of antisemitism in biblical texts, in Christian tradition since the so-called church fathers, in Christian doctrine, and so on. My own perspective is that of a researcher in religious education. That's why I'm especially interested in a critical investigation on current Christian education in terms of anti-Jewish content as well as creating educational concepts to fight antisemitism. For this reason the reminder of this contribution concentrates on what teachers of religious education actually are doing in terms of combating antisemitic prejudices and attitudes in their lessons on religious education in class. This is the focus of an international empirical study with teachers of religious education that was conducted in Germany, Austria, and Switzerland.

2 R. Kampling, "Antijudaismus," in Begriffe, Theorien, Ideologien, vol. 3 of Handbuch des Antisemitismus, ed. W. Benz (Berlin: De Gruyter, 2010), 13. See also: C. Hoffmann, "Christlicher Antijudaismus und moderner Antisemitismus. Zusammenhänge und Differenzen als Problem der historischen Antisemitismusforschung," in Christlicher Antijudaismus und Antisemitismus: Theologische und kirchliche Programme deutscher Christen, ed. L. Siegele-Wenschkewitz (Frankfurt/ M.: Haag und Herchen, 1994), 293-317; R. R. Ruether, Faith and Fratricide: The Theological Roots of Anti-Semitism (New York: Seabury, 1974).

3 Cf. Y. Bauer, "Vom christlichen Judenhass zum modernen Antisemitismus: Ein Erklärungsversuch,” Jahrbuch für Antisemitismusforschung 1 (1992): 77-91; S. Salzborn, Antisemitismus. Geschichte, Theorie, Empirie (Baden-Baden: Nomos, 2014), 11-13. 


\section{Context of the Study}

After the Shoah the shock about what happened was immense-not only in all western societies and nations but also in various religious institutions. Some early Christian reactions immediately after World War II express feelings of guilt and shame in light of what happened, the awareness that the Christian tradition was part of the road that led to Auschwitz. The documents also express the willingness and the need to fight antisemitism, trace the roots of antisemitism in Christian tradition, fundamentally revise Christian doctrine, and teach respect, appreciation, and esteem toward Jews and Judaism. One of the most impressive statements is that of the so-called "Seelisberg Conference," an assembly of Roman Catholic and Protestant Christians together with Jewish representatives that took place in 1947 in Seelisberg, Switzerland. The declaration of "The Ten Points of Seelisberg" (or "The Ten Theses of Seelisberg") was a demanding address to the churches

...to prevent any animosity towards the Jews which might arise from false, inadequate or mistaken presentations or conceptions of the teaching and preaching of the Christian doctrine... ${ }^{4}$

In this document we find a nascent awareness of the fact that Christianity itself is responsible for the rise of antisemitism both in history and the present and that the duty of Christian leaders, pastors, and teachers should be to teach younger generations a new understanding of Jewish-Christian relations and to fight antisemitism. This was also an important point at an assembly of the German Protestant Church (EKD) in 1950 in Berlin. In 1965, the Roman Catholic Church delivered a fundamental declaration on the relationship toward nonChristian religions including Judaism that opened a completely new chapter in church history. The name of the famous document is Nostra Aetate, and it was promulgated at the last session of the Second Vatican Council. For the first time in history, the Jews and Judaism were seen in a positive light in a major official document of the Catholic Church. In Nostra Aetate, Christians and Jews are understood in the frame of a close partnership in the history of salvation. The consequence of this new understanding of the Christian-Jewish relationship is the rejection of antisemitism. The Vatican document states:

4 "The ten points of Seelisberg" reported in: J. Isaac, The Christian Roots of Anti-Semitism (London: Kingham, 1965), 23. 
In her rejection of every persecution against any man, the Church, mindful of the patrimony she shares with the Jews and moved not by political reasons but by the Gospel's spiritual love, decries hatred, persecutions, displays of anti-Semitism, directed against Jews at any time and by anyone. ${ }^{5}$

This declaration was a tremendous step forward, especially mirrored in the numerous following explanations and documents from all Christian churches and assemblies on a national as well as on a global level. Since the 1970s, Christian theology has developed a completely different and renewed doctrine on the positive relationship between Christians and Jews. Theology has specified and clarified the document Nostra Aetate at decisive points. ${ }^{6}$ The renewed church statements and theological approaches were also followed by major initiatives to revise textbooks and curricula in Christian teaching and in religious education-for example, as part of the project called "Learning Process Christians and Jews" conducted by scholars in religious education, which led to a comprehensive revision of German-speaking religious education textbooks. ${ }^{7}$ One of the latest studies is the one by Julia Spichal who focused on still-existing prejudices against Jews in textbooks and curricula of Christian religious education. ${ }^{8}$

In summary, Christian awareness has grown such that right-wing thinking, antisemitic attitudes, xenophobic behaviour, and so on are an important challenge to Christian theology ${ }^{9}$ and religious education. Nevertheless, there are

5 Pope Paul VI, Nostra Aetate: Declaration On The Relation Of The Church To Non-Christian Religions, issued October 28, 1965, accessed July 17, 2018, http://www.vatican.va/archive/hist_ councils/ii_vatican_council/documents/vat-ii_decl_19651028_nostra-aetate_en.html. Cf. also the following commentaries: R. A. Siebenrock, "Nostra Aetate. Theologischer Kommentar," in Herders Theologischer Kommentar zum Zweiten Vatikanischen Konzil, ed. P. Hünermann and B. J. Hilberath (Freiburg: Herder, 2006), 3:591-693; R. Boschki, J. Wohlmuth, and L. Ricken, eds., Nostra Aetate 4: Wendepunkt im Verhältnis von Kirche und Judentum-bleibende Herausforderung für die Theologie (Paderborn: Schöningh, 2015).

6 As an example, one of the latest studies: M. Himmelbauer, M. Jäggle, R. A. Siebenrock, and W. Treitler, eds., Erneuerung der Kirchen. Perspektiven aus dem christlich-jüdischen Dialog (Freiburg: Herder, 2018).

7 E.g. P. Fiedler, Das Judentum im katholischen Religionsunterricht: Analysen, Bewertungen, Perspektiven (Düsseldorf: Patmos, 1980); G. Biemer, Freiburger Leitlinien zum Lernprozess ChristenJuden (Düsseldorf: Patmos, 1981); M. Rothgangel, Antisemitismus als religionspädagogische Herausforderung: Eine Studie unter besonderer Berücksichtigung von Röm 9-11 (Freiburg: Herder, 1995).

8 Cf. J. Spichal, Vorurteile gegen Juden im christlichen Religionsunterricht: Eine qualitative Inhaltsanalyse ausgewählter Lehrpläne und Schulbücher in Deutschland und Österreich (Göttingen: Vandenhoeck \& Ruprecht, 2015).

9 Cf. S. A. Strube, ed., Rechtsextremismus als Herausforderung für die Theologie (Freiburg: Herder, 2015). 
still important tasks to complete for religious education to fight antisemitism. With respect to classroom education, very little is known empirically about what teachers really do. That is the reason why we started an empirical study within religious education that is still in progress and that will continue for the next couple of years.

\section{Our Empirical Study}

\subsection{Theoretical Framework}

The research project REMEMBER ${ }^{10}$ is situated within the frame of Holocaust education and Holocaust remembrance in Europe. The basic theoretical point is that Holocaust remembrance is part of an educational duty of any democratic state-especially of Germany and Austria.

The research project asks, by means of an international comparative approach, how the topic of Holocaust remembrance is dealt with within religious education in the context of schools in Germany, Austria, and Switzerland. ${ }^{11}$ Religious education is mandatory and part of the government-sponsored school systems in the countries that are studied here. Going beyond the theoretical, and mostly normative discourse, the emphasis is set on the empirical investigation of the practice of religious education focusing on Holocaust remembrance. This was examined in three German-speaking countries-Germany, Austria, and Switzerland-via an online questionnaire. This approach provides an overview and statistical data about various ways of teaching Holocaust remembrance and combatting antisemitism.

Some aspects of our theoretical approach are: "Memory" and "remembrance" are not identical with "history," but both concepts are closely linked together. Memory ("remembrance") is a phenomenon that is directly related to the present. It is a specific interpretation and construction of history that is relevant for the present and for the future of society-as well as for the collective identity

10 Cf. Research group REMEMBER, Erinnerung an den Holocaust im Religionsunterricht. Empirische Einblicke und didaktische Impulse (Stuttgart: Kohlhammer, 2020).

11 Members of the research group REMEMBER are: Tübingen University: Reinhold Boschki, Burkard Hennrich, Stefan Lemmermeier, Rebecca Nowack, Angelika Treibel; Zürich University: Thomas Schlag, Michèle Wenger; Vienna University: Sonja Danner, Andrea Lehner-Hartmann, Martin Jäggle, Viera Pirker, Martin Rothgangel, Julia Spichal; Evangelische Hochschule Freiburg: Wilhelm Schwendemann; Mainz University: Stefan Altmeyer, Anna Weber; Katholische Stiftungshochschule München, Campus Benediktbeuern: Ralf Gaus. 
construction of groups within society. In our approach to memory and history, we follow scholar in cultural studies Aleida Assmann in acknowledging that individual and collective memory/remembrance and history/ historiography are different perspectives on the past that are bound together in a dialectical manner "like a system of checks and balances" for mutual completion, control, and correction. $^{12}$

Concerning Holocaust remembrance, we are living in a time of transformational change. ${ }^{13}$ The generation of direct involvement is almost completely gone. The legacy of the Nazi era undergoes a process of historization. Philosophers of history speak of a "paradigm shift" concerning Holocaust remembrance. ${ }^{14}$ This transformational change has multifaceted manifestations.

- Political change:

- expansion of the European Union

- process of globalization

- overlapping memories

- "fight for memory" / "struggle for remembrance"15

- Societal change:

- Societies become rapidly heterogeneous and pluralistic

- migration

- different ethnic communities have their own approaches to memory

- Religious change:

- religion is characterized by heterogeneity, plurality as well

- religious memory in Europe is no longer identical with Christian memory

- individual, societal, and political relevance of religion is signature of socalled post-secularity

- Change of identity constructions:

- mentality transformation

- impact of mass media on individual, social, political, and religious identity constructions

- Change of experienced reality:

12 A. Assmann, Das neue Unbehagen an der Erinnerungskultur: Eine Intervention (München: Beck, 2013), 23.

13 Cf. Z. Gross and E. D. Stevick, eds., As the Witnesses Fall Silent. $21^{\text {st }}$ Century Holocaust Education in Curriculum, Policy and Practice (New York: Springer, 2015); G. Hartman and A. Assmann, Die Zukunft der Erinnerung und der Holocaust (Paderborn: Konstanz University Press, 2012).

14 Cf. D. Diner, Zeitenschwelle: Gegenwartsfragen an die Geschichte (München: Beck, 2010). 15 Cf. C. Leggewie, Der Kampf um die europäische Erinnerung: Ein Schlachtfeld wird besichtigt (München: Beck, 2011). 
- digitalization, increasing importance of new media on all fields of our life also transform the "paradigm of remembrance"16

- Educational change:

- traditional forms of Holocaust education must be "revisited" in a plural and multicultural society.

In the face of these trends the future of Holocaust remembrance is at stake. The questions are how memory and memory work will change and what role religious education can play in that context. Our hypothesis is that religious education is able to provide a substantial contribution to learning remembrance in school education. This process of learning remembrance goes hand in hand with learning to combat antisemitism, racism, and "group focused enmity."17

The first and foremost reason for remembrance of the Holocaust is respect for the victims. Those who have been victimized in the past have the fundamental human right to be remembered by democratic systems today and in the future. Democracy always is the successor of totalitarianism. Therefore, remembering the victims is a democratic act. At the same time, remembrance implies a special function or duty: To never forget what happened in the past helps us to never repeat it in the present and future.

For this reason, Holocaust remembrance and the fight against antisemitism as well as teaching of human rights are linked together as Monique Eckmann, a Swiss sociologist, writes:

... Holocaust education ... helps students see the need to protect human rights... Indeed the destiny of the Jews reveals the extreme vulnerability of stateless persons who are denied any rights at all. ${ }^{18}$

Learning about what happened to Jews and other minorities during the Nazi regime can be a "starting point to confront human rights issues." ${ }^{19}$ In Monique

16 Cf. K. Frieden, Neuverhandlungen des Holocaust: Mediale Transformationen des Gedächtnisparadigmas (Bielefeld: Transcript, 2014).

17 Cf. W. Heitmeyer, ed., Deutsche Zustände (Frankfurt: Suhrkamp, 2012).

18 M. Eckmann, "Is Teaching and Learning about the Holocaust Relevant for Human Rights Education?" in As the Witnesses Fall Silent. $21^{\text {st }}$ Century Holocaust Education in Curriculum, Policy and Practice, ed. Z. Gross and E. D. Stevick (New York: Springer, 2015), 59-60.

19 Ibid., 60; see also: M. Brumlik, "Globales Gedächtnis und Menschenrechtsbildung," in Holocaust und historisches Lernen. Aus Politik und Zeitgeschichte, supplement to Das Parlament 66, nos. 3-4 (2016): 29-37; R. Boschki, B. Reichmann, and W. Schwendemann, "Towards a new Theory of Holocaust Remembrance in Germany: Education, Preventing Antisemitism, and Ad- 
Eckmann's perspective, Holocaust education is not the core of human rights education and teaching against antisemitism, but it could be a starting point, a motivation for an interest in human rights and the mechanisms of antisemitism in the past and in the present.

This comes close to one of the major research questions of our empirical study: How and to what extent can Holocaust education within religious education be part of the fight for human rights and against antisemitism ${ }^{20}$ The specific emphasis of the study is on Holocaust remembrance within religious education. Here we are examining the practice of religious education by analyzing how the complex topics of Holocaust remembrance and antisemitism are approached and perceived by pupils and teachers in the context of this specific school subject.

\subsection{Design and Methodology of the Study}

The research project asks, by means of an international comparative approach, how religious education deals with the topic of Holocaust remembrance and antisemitism in the context of secondary schools in Germany, Austria, and Switzerland. The goal was (and still is) to get a survey on what happens in the classroom with respect to Holocaust remembrance and teaching against antisemitism from the perspective of the teachers. For this reason the study is an evaluation study or inventory study in order to get an overview of the state of the art of religious education in terms of Holocaust education and antisemitism prevention.

The online questionnaire generated statistical data that represents the quantitative aspect of our study. In a second step the online questionnaire explores short texts written by the teachers involved, initiated by open questions. This represents the qualitative part of the study. Analyzing these texts provide deeper insights concerning teachers' experiences, obstacles, and achievements in class while covering the topic of antisemitism. The country-specific frameworks are analyzed with the help of curricula analysis methods and content analysis of teaching guidelines and materials. All these parts of the study are in process, especially the curriculum analysis and the analysis of the qualitative data.

vancing Human Rights," in As the Witnesses Fall Silent. $21^{\text {st }}$ Century Holocaust Education in Curriculum, Policy and Practice, ed. Z. Gross and E. D. Stevick (New York: Springer, 2015), 469-88. 20 Cf. R. Boschki, "Human Rights Education in the Context of a 'Culture of Remembrance', in Human Rights and Religion in Educational Contexts, ed. M. Pirner, J. Lähnemann, and H. Bielefeldt (Bern: Springer, 2016), 209-18. 
The online questionnaire was open on the internet between August 2016 and May 2017. There were 1,257 teachers who participated in the study, completed the questionnaire, and sent it online back to us. There were 1,201 questionnaires that were filled out completely. Eight-hundred and fifty-seven persons from Germany participated (ca. 72\%), 219 from Austria (ca. 18\%), and 125 from Switzerland (ca. 10.5\%). The percentage figures roughly represent the number of religious education teachers in the three countries. Nevertheless, this is not a representative study because the sample of participants is not a representative one. The detail of who received the information about our project and about the online questionnaire is random and not led by representative strategies-this is the nature of online questionnaires.

The data given distinguished insights into teachers' actions and thinking about teaching Holocaust education and teaching against antisemitism.

Some exemplary questions of our online questionnaire are:

- Which topics are most important for you while teaching about the Holocaust within religious education?

- Which didactical elements do you prefer? (e.g., teaching in the classroom; undertaking excursions to historical sites like former concentration camps, traces of Jewish life before the Nazi period like Jewish cemeteries or former synagogues; showing movies in class; initiating discussion groups in classroom; reading texts and testimonies of victims or survivors, etc.)

- Are students of today ready and willing to discuss topics like the Holocaust in class?

- What are the main obstacles and resistance to the topic?

- Do you see connections between Holocaust education and today's problems and developments in society and politics (e.g., xenophobia, refugee crisis, resurgent antisemitism)?

We analyzed the statistical data with help of computer program SPSS and the qualitative data with the help of MAXQDA.

\subsection{Some Selected Results}

As stated above, our analysis of data is still in process. I would like to present here just some of our observations concerning the topic of combating antisemitism. 


\begin{tabular}{ll}
\hline $\begin{array}{l}\text { Question 5: Which topics are most important for you while teaching about the } \\
\text { Holocaust within religious education? }\end{array}$ & $\begin{array}{l}\text { percentage } \\
\text { (\%) }\end{array}$ \\
\hline Resistance against NS & 60.6 \\
Current situation: How to deal with foreigners (e.g., refugees) today & 54.1 \\
Learning from history for today & 53.4 \\
Anti-Judaism, antisemitism in the past & 51.8 \\
Antisemitism today & 38.9 \\
\hline
\end{tabular}

Question 33 asks for connections between Holocaust education and today's issues and problems in society and politics. Many of the participating teachers see connections between the past and the present. Antisemitism and antiJudaism in the past must be studied and understood in order to understand current social mechanisms that lead to antisemitism today.

\subsubsection{Antisemitism is Present in Society and Schools}

Some teachers see clearly that antisemitic attitudes are still present in our society and that there is a need for confronting students about anti-Jewish thinking. It is important to discuss this problem and to help students to get a "true" picture of Jewish life and Judaism: "Even if it is not talked about publicly, antisemitism is deeply rooted and conversations are often enlightening." 21 Other religious education teachers write:

- "I have been teaching religion for 30 years and I'm convinced that it is more important than ever to keep alive the memory of the Holocaust and to stand up against racism and antisemitism!!!”

- "I'm teaching Holocaust remembrance so that students become sensitive and immune to right-wing and antisemitic ideas."

- "Holocaust education belongs to the syllabus and is pedagogically appropriate as a critique of the currently latent antisemitism (and racism in general)."

- "Antisemitism is on the agenda in my sixth grade. However, it is discussed again and again-even in other grades-if students want to discuss it (because of current events or because a student makes an antisemitic or xenophobic comment)."

21 Quotations by participants of our study are printed in italics (here and following) to distinguish them from the author's own understanding of the discussed problem and topic. 
In the study, the participating teachers of religious education show a sensitive perception of the social situation and the situation in schools as far as antisemitism is concerned. They are trying to respond to it through their teaching.

\subsubsection{Remembering the Shoah}

Concerning the question about a connection between the Shoah and current issues one of the teachers writes:

I cannot answer that easily. For many students, these may be two separate issues that do not have much to do with each other. Some, on the other hand, who engage in remembering the Shoah, recognize the connection without further intervention from the teacher. Xenophobia was and is always an issue in the classroom. Social antisemitism still exists. It has even experienced a renaissance, initiated by various Internet and youtube posts.

Other teachers argue:

The relationship between Jews and Christians is important. The reasons that led to the Shoah must also be examined in religious terms... [It is important to focus on remembrance of the Holocaust] because it's important that we never forget what happened. So that students can learn from it for the future.

Other teachers ask themselves: What can be done in religious education to prevent antisemitism and to teach against it? Could Holocaust education be a "remedy" for antisemitism?

First of all, the Holocaust should be portrayed as such; students should be given the opportunity to deal with it without a quick connection to human rights issues of today...-After that we should teach our responsibility today, to fight against xenophobia and antisemitism.

This quote of a religious education teacher is of special interest because it expresses the importance of not "using" Holocaust education as a "tool" or a means to prevent xenophobia and antisemitism in our time. This ultimately would do no justice to the victims of the Shoah.

On the other hand, Holocaust remembrance can be a motivation to deal with topics of hate, violation of human rights, and antisemitism today. Teachers of religious education see a possibility to sensitize young people in focusing on specific biographies-not (only) on figures and numbers:

Biography work (e.g. Elie Wiesel, Samuel Pisar or Saul Friedländer) with people who survived the concentration camps as adolescents and helped us to derive consequences, can become 
an anchor for dealing with antisemitism, totalitarian power and the perspective of a free and plural society.

To understand the biography of one of the victims or survivors could help students understand in an exemplary way the mechanisms of discrimination, exclusion, oppression, deportation, and extermination. This could be "an anchor for dealing with antisemitism" in the past and in the present.

Others prefer to show and discuss movies on the Holocaust (almost half of participating teachers), visit memorial sites, such as concentration camps or visit Jewish communities and synagogues to get in touch with Jewish life today. Some teachers invite Jews to their classroom, some make bicycle excursions to find traces of former Jewish life in a town or in small villages nearby. Some teachers read books like Night by Elie Wiesel in their religious education classes, some visit Jewish museums, others cooperate with Yad Vashem.

\subsubsection{The Contribution of Religious Education}

Question 28 of our questionnaire is of special interest from the perspective of religious education research. The question asks about the special contribution of religious education to remembrance of the Holocaust. Many teachers answer that the distinguishing characteristic of religious education is to inform about $r e$ ligious sources of antisemitism:

- "Showing the religious roots of anti-Judaism / antisemitism; showing the inconsistency of the image of man behind antisemitism with the Christian faith."

- "In grade 9, I put an emphasis in the accurate analysis of anti-Jewish and antisemitic prejudices, their biblical roots and their interplay. That does not appear in any textbook."

- "The responsibility of the church for the religious antisemitism makes it necessary to teach about it. Knowledge about history can strengthen students in assessing current developments.”

From the perspective of religious education teachers, the contribution of religious education to prevent antisemitism is to study the religious sources of antisemitism, to unmask Christian and biblical roots of anti-Jewish attitudes and to sensitize religious education students for current antisemitic thoughts. Christian religious education has an obligation to transform former hate against Jews in solidarity with Jews and Judaism today. This issue in teaching is not only motivated by human, political, and social reasons but also by a new theological understanding of the close relationship between Christians and Jews: 
- "Judaism and the relationship between Christianity and Judaism should be an important part of Christian religious education."

- "Historically, Christians have a special relationship with people of Jewish faith, therefore they have a special responsibility."

Some say that is exactly the reason why Christian religious education should deal with the subject of anti-Judaism and antisemitism:

Because it is part of the Christian faith to keep alive the memory of the victims, but also to reveal traces of hope in the terrible events and to encourage that we can fight against exclusion processes. Because from the perspective of religious education, questions like how are people able to do such terrible things can be discussed more intensively than in history lessons (also a question for theodicy).

Another "anchor" for dealing with antisemitism is seen in the Christian faith itself:

The core of religious education is a statement of faith: Every human being is an image of God. It was trampled upon (on an industrial scale in the Holocaust). We also trample on it today, in exaggerated nationalism, in the persecution of minorities, in the violation of the human dignity of refugees and others.

Religious education has the task to stand up for other people who are in danger, who are threatened, and persecuted. And especially for the Jews. The rich material of data reveals plenty of possibilities to sensitize students and learners against antisemitism today.

Many teachers write that they create their own didactical material because textbooks mostly deal with the topic of Holocaust remembrance and antisemitism in a too superficial way, as they argue. Indeed, in the data we received, we could see an extraordinary creativity and commitment with many religious education teachers who give lessons on Holocaust remembrance and combatting antisemitism. Very often religious education teachers are promoters of a "culture of remembrance" in schools and of an atmosphere of sensitivity for human rights and for human dignity of all ethnic, social, and religious groups-including Jews and Judaism. 


\section{Consequences and Theses for Discussion}

In this contribution, I only could provide a few insights and some of the results of our empirical research. We have analyzed the data and described the most important results in more detail in our book. This will be the starting point for future studies to deepen our research-for example, in conducting qualitative interviews with religious education teachers, exploring instruction courses, ethnographic studies of classroom interaction, and of field trips (especially to former concentration camps), group interviews with young people, and so on.

Our basic theses that are derived from our theoretical framework are also mirrored in the data we collected in our empirical work. I would like to discuss the following points:

- Holocaust remembrance is not identical with the fight against antisemitism, racism, and xenophobia today. Memory of the Holocaust means, above all, the remembrance of the victims, their lives, their deaths, and their legacies.

- On the other hand, Holocaust remembrance can be a starting point, a motivation, or-according to one of the teachers-an "anchor" for dealing with antisemitism today. It can also be a motivation for studying the violation of human rights in general and the mechanism of group-focused enmity.

- Religious education can provoke deeper insights and reflections on the religious origins of antisemitism and initiate an awareness of the specific bond between Judaism and Christianity. In this respect, religious education supplements the work on these issues in lessons for history and social studies.

Religious education tries to give a special contribution to a holistic and integral education of young people. Human rights education and the fight against antisemitism are important parts of education in general but also crucial for religious education in particular. The great challenge for teachers in religious education in the context of Holocaust remembrance and the fight against antisemitism is to sensitize themselves in order to be able to sensitize students and learners.

Reinhold Boschki is professor of religious education in the Faculty of Catholic Theology at the University of Tübingen, Germany. He directs the Elie Wiesel Research Center and conducts research, including culture of remembrance with regard to the Shoah, and religious education that is critical of antisemitism. 


\section{References}

Assmann, Aleida. Das neue Unbehagen an der Erinnerungskultur: Eine Intervention. München: Beck, 2013.

Bauer, Yehuda. "Vom christlichen Judenhass zum modernen Antisemitismus: Ein Erklärungsversuch.” Jahrbuch für Antisemitismusforschung 1 (1992): 77-91.

Biemer, Günter. Freiburger Leitlinien zum Lernprozess Christen-Juden. Düsseldorf: Patmos, 1981.

Boschki, Reinhold. "Human Rights Education in the Context of a 'Culture of Remembrance'." In Human Rights and Religion in Educational Contexts, edited by Manfred L. Pirner, Johannes Lähnemann, and Heiner Bielefeldt, 209-18. Bern: Springer, 2016.

Boschki, Reinhold, Bettina Reichmann, and Wilhelm Schwendemann. "Towards a new Theory of Holocaust Remembrance in Germany: Education, Preventing Antisemitism, and Advancing Human Rights." In As the Witnesses Fall Silent. $21^{\text {st }}$ Century Holocaust Education in Curriculum, Policy and Practice, edited by Zehavit Gross and E. Doyle Stevick, 469-88. New York: Springer, 2015.

Boschki, Reinhold, Josef Wohlmuth, and Lukas Ricken, eds. Nostra Aetate 4: Wendepunkt im Verhältnis von Kirche und Judentum-bleibende Herausforderung für die Theologie. Paderborn: Schöningh, 2015.

Brumlik, Micha. "Globales Gedächtnis und Menschenrechtsbildung." In Holocaust und historisches Lernen. Aus Politik und Zeitgeschichte. Supplement to Das Parlament 66, nos. 3- 4 (2016): 29-37.

Diner, Dan. Zeitenschwelle: Gegenwartsfragen an die Geschichte. München: Beck, 2010.

Eckmann, Monique. "Is Teaching and Learning about the Holocaust Relevant for Human Rights Education?" In As the Witnesses Fall Silent. $21^{\text {st }}$ Century Holocaust Education in Curriculum, Policy and Practice, edited by Zehavit Gross and E. Doyle Stevick, 53-65. New York: Springer, 2015.

Fiedler, Peter. Das Judentum im katholischen Religionsunterricht: Analysen, Bewertungen, Perspektiven. Düsseldorf: Patmos, 1980.

Frieden, Kirstin. Neuverhandlungen des Holocaust. Mediale Transformationen des Gedächtnisparadigmas. Bielefeld: Transcript, 2014.

Gross, Zehavit, and E. Doyle Stevick, eds. As the Witnesses Fall Silent. $21^{\text {st }}$ Century Holocaust Education in Curriculum, Policy and Practice. New York: Springer, 2015.

Hartman, Geoffrey, and Aleida Assmann. Die Zukunft der Erinnerung und der Holocaust. Paderborn: Konstanz University Press, 2012.

Heitmeyer, Wilhelm, ed. Deutsche Zustände. Frankfurt: Suhrkamp, 2012.

Himmelbauer, Markus, Martin Jäggle, Roman A. Siebenrock, and Wolfgang Treitler, eds. Erneuerung der Kirchen. Perspektiven aus dem christlich-jüdischen Dialog. Freiburg: Herder, 2018.

Hoffmann, Christhard. "Christlicher Antijudaismus und moderner Antisemitismus. Zusammenhänge und Differenzen als Problem der historischen Antisemitismusforschung." In Christlicher Antijudaismus und Antisemitismus: Theologische und kirchliche Programme deutscher Christen, edited by Leonore Siegele-Wenschkewitz, 293-317. Frankfurt/M.: Haag und Herchen, 1994.

Isaac, Jules. The Christian Roots of Anti-Semitism. London: Kingham, 1965. 
Kampling, Rainer. “Antijudaismus." In Begriffe, Theorien, Ideologien. Vol. 3 of Handbuch des Antisemitismus, edited by Wolfgang Benz, 10-13. Berlin: De Gruyter, 2010.

Leggewie, Claus. Der Kampf um die europäische Erinnerung: Ein Schlachtfeld wird besichtigt. Munich: Beck, 2011.

Pope Paul VI. Nostra Aetate: Declaration On The Relation Of The Church To Non-Christian Religions. Issued October 28, 1965. Accessed July 17, 2018. http://www.vatican.va/ar chive/hist_councils/ii_vatican_council/documents/vat-ii_decl_19651028_nostra-aetate_ en.html.

Research group REMEMBER. Erinnerung an den Holocaust im Religionsunterricht. Empirische Einblicke und didaktische Impulse. Stuttgart: Kohlhammer, 2020.

Rosenfeld, Alvin H., ed. Resurgent Antisemitism: Global Perspectives. Bloomington: Indiana University Press, 2013.

Rothgangel, Martin. Antisemitismus als religionspädagogische Herausforderung. Eine Studie unter besonderer Berücksichtigung von Röm 9-11. Freiburg: Herder, 1995.

Ruether, Rosemary Radford. Faith and Fratricide: The Theological Roots of Anti-Semitism. New York: Seabury, 1974.

Salzborn, Samuel. Antisemitismus. Geschichte, Theorie, Empirie. Baden-Baden: Nomos, 2014.

Siebenrock, Roman A. "Nostra Aetate. Theologischer Kommentar." In Herders Theologischer Kommentar zum Zweiten Vatikanischen Konzil, edited by Peter Hünermann and Bernd Jochen Hilberath, 3:591-693. Freiburg: Herder, 2006.

Spichal, Julia. Vorurteile gegen Juden im christlichen Religionsunterricht: Eine qualitative Inhaltsanalyse ausgewählter Lehrpläne und Schulbücher in Deutschland und Österreich. Göttingen: Vandenhoeck \& Ruprecht, 2015.

Strube, Sonja Angelika, ed. Rechtsextremismus als Herausforderung für die Theologie. Freiburg: Herder, 2015. 